\title{
Impact of Land Configurations and Nutrient Levels on Growth and Yield of Sunflower under Rainfed Condition
}

\author{
Kokila Bhople*, K.J. Kubde, Bharti Tijare and Godavari Gaikwad \\ Department of Agronomy, Dr. Panjabrao Deshmukh Krishi Vidyapeeth, Akola (MS), India \\ *Corresponding author
}

\begin{tabular}{|l|}
\hline K e y w o r d s \\
Growth, Land \\
configuration, \\
Nutrient levels, \\
Sunflower and \\
Yield
\end{tabular}

\section{Introduction}

Sunflower (Helianthus annuиs L.) oil is preferred among the consumers in India for its health benefits and sunflower oil is the largest selling oil in the branded oil segment. It is also a crop of choice for farmers due to its wider adaptability, high yield potential, shorter duration and profitability. Presently in India sunflower is grown over an area of 5.51 lakh hectares with a production of about 4.15 lakh

tonnes and average productivity of $752 \mathrm{~kg}$ per hectare. In Maharashtra it is grown over an area of 0.46 lakh hectares with a production of about 0.19 lakh tonnes and the productivity is $425 \mathrm{~kg}$ per hectare (Anonymous, 2016). The major reason for low productivity is due to its cultivation mainly under rainfed conditions with sub optimal crop stand, imbalanced 
nutrition and lack of soil moisture conservation techniques, thus leading to poor seed set and high per cent of chaffy seed, low oil content and yield.

The crops grown under rainfed condition are either subjected to excess water or water deficit condition. Intermittent dry spell of 10 to 15 days or even more are commonly observed affecting growth of the crop. Therefore it is necessary to reduce water loss from soil. Under rainfed conditions, response to the applied fertilizers varies with the available soil moisture. Hence, efficient soil moisture conservation is the key for successful crop production under this situation. Application of fertilizers having nutrients viz., nitrogen, phosphorous and potash can increase sunflower growth and yield substantially (Reddy et al., 2007). Intensive agriculture with fertilizer use is highly skewed towards nitrogen, has deprived the soil of other essential nutrients, especially $\mathrm{P}$ and $\mathrm{K}$. Hence, balanced fertilizer application is important for high seed and oil yield. Appropriate combination of land configuration along with nutrient levels not only meets the crop nutrient requirements and sustain productivity but also improve soil health. Considering these facts the present study has been undertaken to study the effect of land configurations and nutrient levels to improve the productivity of sunflower.

\section{Materials and Methods}

The present experiment on sunflower was conducted during kharif 2015 at Oilseed Research Unit farm, Dr. PDKV, Akola. The soil of experimental site was clay loam with $\mathrm{pH}$ of 8.1 , electrical conductivity $0.32 \mathrm{dSm}^{-1}$, low in organic carbon $(0.38 \%)$, low in available nitrogen (181.17 $\mathrm{kg} \mathrm{ha} \mathrm{ha}^{-1}$ and phosphorus (14.12 $\mathrm{kg} \mathrm{ha}^{-1}$ ) and marginally high in available potassium (323.33 $\mathrm{kg} \mathrm{ha}^{-1}$ ). The experiment was laid out in split plot design consisting of twelve treatments combinations and replicated thrice. The main plots consisted of : $\mathrm{L}_{1}$ - Flat bed, $\mathrm{L}_{2}$ - Ridges and furrow, $\mathrm{L}_{3}$ - Paired row planting and $\mathrm{L}_{4}-$ Broad bed and furrow and $\mathrm{N}_{1}-75 \% \mathrm{RDF}, \mathrm{N}_{2}$ $100 \%$ RDF (80:60:30 N, $\mathrm{P}_{2} \mathrm{O}_{5}$ and $\mathrm{K}_{2} \mathrm{O} \mathrm{kg}$ $\mathrm{ha}^{-1}$ ) and $\mathrm{N}_{3^{-}} 125 \%$ RDF were the sub plot treatments. The sunflower hybrid (DRSH-1) was sown on $7^{\text {th }}$ August and harvested on $6^{\text {th }}$ November, 2015. Full dose of $\mathrm{P}_{2} \mathrm{O}_{5}$ and $\mathrm{K}_{2} \mathrm{O}$ along with half of the nitrogen in all the treatments was applied as basal. Remaining nitrogen was applied at 30 DAS as per the treatments. Need based plant protection measures were taken. The crop was grown completely under rainfed conditions. A total of $258.4 \mathrm{~mm}$ rainfall was received in 12 rainy days during the crop growth period.

\section{Results and Discussion}

\section{Growth and growth attributes}

The data from Table 1 indicated that the land configuration technique of ridges and furrow recorded maximum plant height which was at par with broad bed furrow, both these treatments were significantly superior over paired row planting and flatbed which were also statistically similar in respect of plant height. Application of $125 \% \mathrm{RDF}$ remains at par with $100 \%$ RDF and recorded significantly higher plant height over $75 \%$ RDF. Application of $100 \% \mathrm{RDF}$ and $75 \%$ RDF were similar in respect of plant height. The increase in plant height with increase in nutrient management might have attributed to greater availability of nutrients with increase in application rate which might have favourable effect on plant growth. Similar results were observed by Byomkesh et al., (2014).

The data in respect of functional leaves indicated that ridges and furrow and broad bed furrow both being at par and recorded 
significantly more number of functional leaves than the paired row planting and flatbed which were also remain at par with each other in respect of functional leaves. Application of $125 \% \mathrm{RDF}$ and $100 \%$ RDF both treatments being at par produced significantly higher number of functional leaves than the $75 \%$ RDF level.

Treatment ridges and furrow, broad bed furrow and paired row planting were statistically equal in effect and recorded significantly more stem girth than the flat bed.

Application of $125 \%$ RDF being at par with $100 \%$ RDF recorded significantly higher stem girth than the $75 \%$ RDF, which was at par with $100 \%$ RDF level. Similar results were also reported by Solangi et al., (1999)

Significant increased in growth attributes with ridges and furrow and broad bed furrow as compared to paired row planting and flatbed indicated adequate moisture conservation in soil, resulting in good supply of required moisture, available nutrients, soil aeration which has benefited to the crop during growth period, resulted in optimum cell division and their elongation which resulted in enhanced plant height, number of functional leaves and stem girth. The results were in conformity with those reported by Ahmad et al., (2000)

The dry matter production per plant was significantly higher with ridges and furrow than the paired row planting and flatbed but was at par with broad bed furrow which was significantly superior over flat bed and at par with paired row planting. Increased moisture availability in root zone due to ridges and furrows increases the availability of nutrients as well as nutrient uptake which led to increase in the overall growth of crop and the resultant increase in dry matter accumulation. Elevated moisture content $(\%)$ in ridges and furrows might have helped the sunflower crop to record higher dry matter. These results were supported with the findings of Kalegore and Girme (2009).

Table.1 Effect of land configurations and nutrient levels on growth and growth attributes

\begin{tabular}{|c|c|c|c|c|}
\hline Treatments & $\begin{array}{l}\text { Plant } \\
\text { height }\end{array}$ & $\begin{array}{c}\text { No. of functional } \\
\text { leaves }\end{array}$ & $\begin{array}{c}\text { Stem } \\
\text { Diameter }\end{array}$ & $\begin{array}{c}\text { Dry matter } \\
\text { accumulation }\end{array}$ \\
\hline \multicolumn{5}{|c|}{ 1. Main plot (Land configuration) } \\
\hline $\mathrm{L}_{1}$-Flat bed & 167.52 & 26.02 & 1.72 & 154.56 \\
\hline $\mathrm{L}_{2}$-Ridges and furrows & 175.56 & 29.50 & 1.84 & 168.54 \\
\hline $\mathrm{L}_{3}$-Paired row planting & 168.11 & 27.80 & 1.78 & 159.33 \\
\hline$L_{4}$ - Broad bed furrow & 174.07 & 29.02 & 1.82 & 162.66 \\
\hline $\mathrm{SE}(\mathrm{m}) \pm$ & 1.64 & 0.71 & 0.03 & 1.95 \\
\hline CD at $5 \%$ & 5.66 & 2.44 & 0.09 & 6.75 \\
\hline \multicolumn{5}{|c|}{ 2. Sub-plot (Nutrient levels) } \\
\hline$N_{1}-75 \%$ RDF & 167.67 & 26.02 & 1.75 & 156.33 \\
\hline $\mathrm{N}_{2}-100 \%$ RDF & 171.19 & 29.50 & 1.78 & 162.66 \\
\hline $\mathrm{N}_{3}-125 \%$ RDF & 175.08 & 27.80 & 1.84 & 165.67 \\
\hline $\mathrm{SE}(\mathrm{m}) \pm$ & 1.31 & 29.02 & 0.02 & 1.74 \\
\hline CD at $5 \%$ & 3.96 & 0.71 & 0.07 & 5.21 \\
\hline \multicolumn{5}{|l|}{ 3. Interaction $(\mathrm{L} \times \mathrm{N})$} \\
\hline $\mathrm{SE}(\mathrm{m}) \pm$ & 2.63 & 0.78 & 0.05 & 3.48 \\
\hline CD at $5 \%$ & NS & NS & NS & NS \\
\hline
\end{tabular}


Table.2 Yield attributes, yield and economics of sunflower as influenced by land configuration and nutrient levels

\begin{tabular}{|c|c|c|c|c|c|c|c|}
\hline Treatment & $\begin{array}{l}\text { Diameter } \\
\text { of disc }\end{array}$ & $\begin{array}{c}\text { Filled } \\
\text { seed }\end{array}$ & $\begin{array}{l}\text { Seed yield } \\
\text { plant }^{-1}(g)\end{array}$ & $\begin{array}{c}100 \text { seed } \\
\text { weight }(g)\end{array}$ & $\begin{array}{l}\text { Seed yield } \\
\left(\mathrm{kg} \mathrm{ha}^{-1}\right)\end{array}$ & $\begin{array}{c}\text { NMR } \\
\left(\text { Rs. ha }^{-1}\right)\end{array}$ & $\begin{array}{c}\text { B:C } \\
\text { Ratio }\end{array}$ \\
\hline \multicolumn{8}{|c|}{ Main plot (Land configuration) } \\
\hline $\mathrm{L}_{1}$-Flat bed & 14.82 & 599 & 28.83 & 3.66 & 1081 & 17943 & 2.00 \\
\hline $\begin{array}{l}\mathrm{L}_{2} \text {-Ridges and } \\
\text { furrows }\end{array}$ & 15.44 & 758 & 35.14 & 3.95 & 1316 & 24032 & 2.26 \\
\hline $\begin{array}{l}\mathrm{L}_{3} \text {-Paired row } \\
\text { planting }\end{array}$ & 15.21 & 685 & 29.44 & 3.78 & 1209 & 21188 & 2.13 \\
\hline $\mathrm{L}_{4}$ - Broad bed furrow & 15.37 & 729 & S32.00 & 3.87 & 1268 & 22206 & 2.14 \\
\hline $\mathrm{SE}(\mathrm{m}) \pm$ & 0.35 & 18 & 1.00 & 0.17 & 28 & - & - \\
\hline $\mathrm{CD}$ at $5 \%$ & NS & 64 & 3.46 & NS & 97 & - & - \\
\hline \multicolumn{8}{|c|}{ Sub-plot (fertilizer levels) } \\
\hline $\mathrm{N}_{1}-75 \% \mathrm{RDF}$ & 14.68 & 625 & 28.60 & 3.70 & 1103 & 18647 & 2.06 \\
\hline $\mathrm{N}_{2}-100 \% \mathrm{RDF}$ & 15.06 & 705 & 31.30 & 3.56 & 1186 & 20235 & 2.07 \\
\hline $\mathrm{N}_{3}-125 \% \mathrm{RDF}$ & 15.89 & 749 & 34.17 & 4.18 & 1367 & 25145 & 2.27 \\
\hline $\mathrm{SE}(\mathrm{m}) \pm$ & 0.31 & 13 & 0.62 & 0.15 & 21 & - & - \\
\hline $\mathrm{CD}$ at $5 \%$ & 0.93 & 41 & 1.87 & 0.44 & 63 & - & - \\
\hline \multicolumn{8}{|l|}{ Interaction ( $\mathbf{L} \times \mathbf{N})$} \\
\hline $\mathrm{SE}(\mathrm{m}) \pm$ & 0.062 & 28 & 1.27 & 0.29 & 42 & - & - \\
\hline $\mathrm{CD}$ at $5 \%$ & NS & NS & NS & NS & NS & - & - \\
\hline
\end{tabular}

Each increment in nutrient levels significantly increased dry matter accumulation per plant. At harvest, application of $125 \% \mathrm{RDF}$ and $100 \%$ RDF remain at par and produced significantly higher dry matter than the $75 \%$ RDF. Increased application of nutrients which increased leaf photosynthetic rate which might have resulted in higher accumulation of metabolites in both vegetative and reproductive fractions thus resulted significant gain in total dry matter per plant in response to increased rate of nutrients application. These results were supported with the findings of Byomkesh et al., (2014)

\section{Yield and yield attributes}

The data in the Table 2 indicated that, land configurations had no significant effect on diameter of disc. Application of $125 \%$ RDF remain at par with $100 \% \mathrm{RDF}$ and registered significantly higher diameter of disc than the $75 \%$ RDF level, which was at par with $100 \%$ RDF.

Number of filled seeds disc $^{-1}$ differed significantly due to land configurations. The ridges and furrow, broad bed furrow, and paired row planting treatment remain at par and recorded significantly higher number of filled seeds per disc than the flat bed treatments. Higher filled seed $\mathrm{disc}^{-1}$ under ridges and furrow, broad bed furrow and paired row planting could be attributed to the adequate availability of soil moisture over other treatments. These findings are in close accordance with Byomkesh et al., (2014).

Among the fertilizer levels application of 125 $\% \mathrm{RDF}$ and $100 \% \mathrm{RDF}$ both remain at par and recorded significantly more number of filled seeds than $75 \%$ RDF treatment. 
Cumulative effect of improved growth parameters (plant height and dry matter accumulation) through efficient metabolic activity, increased photosynthetic rate and supply of photosynthates from source to sink had accommodated more number of filled seeds Disc ${ }^{-1}$ under $125 \%$ RDF. These results are in line with those of Thorat et al., (2007).

The seed yield plant $^{-1}$ differed significantly due to land configurations. The treatment ridges and furrow remain at par with broad bed furrow and recorded significantly higher seed yield plant ${ }^{-1}$ than the paired row planting and flat bed, which were also statistically comparable with paired row planting. The seed yield plant ${ }^{-1}$ significantly increased with every increased fertilizer level. Application of $125 \%$ RDF recorded highest seed yield plant $^{-1}$ followed by $100 \%$ RDF and $75 \%$ RDF. Maximum seed yield plant $^{-1}$ with application of 125 percent RDF is due to maximum head diameter, more number of seed plant ${ }^{-1}$ and the highest test weight in this treatment. This finding is in close proximity with that of Thorat et al., (2007) in sunflower.

The hundred seed weight was found to be non-significant due to different land configuration treatment. While the Application of $125 \%$ RDF registered significantly higher hundred seed weight than $100 \% \mathrm{RDF}$ and $75 \% \mathrm{RDF}$, which were at par with each other.

Treatment ridges and furrow (1316 $\left.\mathrm{kg} \mathrm{ha}^{-1}\right)$ recorded significantly higher seed yield than the paired row planting (1209 kg ha $\left.{ }^{-1}\right)$ and flatbed $\left(1081 \mathrm{~kg} \mathrm{ha}^{-1}\right)$, whereas it remain at par with broad bed furrow $\left(1268 \mathrm{~kg} \mathrm{ha}^{-1}\right)$ and paired row planting were also significant over flat bed in respect of seed yield. The significant increase in weight of disc, number of filled seed, seed yield per plant under ridges and furrow, broad bed furrow and paired row planting ultimately resulted into higher seed yield per hectare over flat bed. Similar type of results was reported by Malik et al., (2001). Among the nutrient levels, application of $125 \%$ RDF (1367 kg ha $\left.{ }^{-1}\right)$ recorded significantly higher seed yield of sunflower over $100 \%$ RDF (1186 $\left.\mathrm{kg} \mathrm{ha}^{-1}\right)$ and $75 \%$ RDF (1103 $\mathrm{kg} \mathrm{ha}^{-1}$ ) level, which were statistically equal in seed yield. These findings corroborate with those of Nandhagopal et al., (2003).

\section{Economics}

Higher net monetary returns and $\mathrm{B}: \mathrm{C}$ ratio were obtained in ridges and furrow. The net monetary returns and $\mathrm{B}: \mathrm{C}$ ratio were found higher under $125 \%$ RDF level than the $100 \%$ and $75 \%$ RDF level. Profound influence of land configuration for better crop growth and yield could result in improving the net returns and benefit cost ratio underridges and furrow and broad bed furrow over paired row planting and flat bed methods. These findings are in close accordance with Somasundaram et al., (2000).

\section{References}

Ahmad, G., Z. Quresh and H. Ullah, 2000. Effect of different sowing methods on performance of sunflower. Pak. J. Bio. Sci., 3 (11): 1829-1830.

Anonymous 2016. Annual report on sunflower, AICRP on sunflower, ICAR, Rajendranagar, Hyderabad.

Byomkesh Let, K. Bhanu Rekha, S.N. Sudhakara Babu and A. Madhavi, 2014.Growth and yield of sunflower as influenced by planting geometry and land configurations under different fertilizer levels. Research note, J. Res. ANGRAU 42(2) 54-57.

Kalegore, N.K. and Girme, M.R. 2009. Effect of land configuration and fertilizer level on yield and quality of sunflower hybrids. M.Sc. (Agri). Thesis submitted 
to VNMKV, Parbhani. pp. 58.

Malik, M.A., S.H. Shah, Sultan Mahmood and Mumtaz Akhtar Cheema, 2001. Effect of Various Planting patterns on the Growth, Seed Yield and Oil Content of New Sunflower Hybrid (SF-187). Int. J. Agric. Biol., 29(3): 1556-1560.

Nandhagopal, A., K. S. Subramanian and A. Gopalan, 1995. Response of sunflower hybrids to nitrogen and phosphorus under irrigation conditions. Madras J. agric. Res. 82(2): 80-83

Reddy, B.N, Sudhakara Babu, S.N and K. Bhanu Rekha, 2007. Productivity and nutrient uptake of sunflower (Helianthus annuus L.) as influenced by site-specific integrated nutrient management on alfisols. J. Oilseeds Res., 24(2): 331-333.

Somasundaram E.A., Jauhar Ali, M.L. Manoharan and A. Arokiaraj 2000. Response of crops to different land management practices under sodic soil conditions. Indian J. Agronomy. 45(1): 92-96.

Thorat, D.G., Abdul Hamid, Giri, M.D., Mohammad Sajid and Katore, J.R. 2007. Effect of irrigation, phosphorus and sulphur on growth and yield attributes of rabi sunflower. Ann. Plant Physiol., 21(1): 71-74.

\section{How to cite this article:}

Kokila Bhople, K.J. Kubde, Bharti Tijare and Godavari Gaikwad. 2018. Impact of Land Configurations and Nutrient Levels on Growth and Yield of Sunflower under Rainfed Condition. Int.J.Curr.Microbiol.App.Sci. 7(01): 363-368. doi: https://doi.org/10.20546/ijcmas.2018.701.041 